УДК: 811.111

DOI: 10.31475/fil.dys.2018.08.14

ЛЮДМИЛА ВОРОТНЯК, кандидат педагогічних наук, доцент (л. Хлельницький)

\title{
Функціонування прецедентних феноменів в англомовному газетному дискурсі
}

У статті виявлено та схарактеризовано такі основні фбункиї прецедентних фбеноленів в англоловнолу газетнолу дискурсі: фбункиію характеризацї, фбункиію експресивності, нолінативну, парольну та маніпулятивну фбункиї. Встановлено, що фбункиї прецедентних беноменів увиразнюють текст та здійснюють прихований вплив на борлування думок, переконань адресата.

Ключові слова: прецедентні фбенолени, газетний дискурс, фбункиія характеризацї, фбункиія експресивності, парольна фбункціл, маніпулятивна фбункиія.

Постановка проблели у загальнолу вигляді... Аналіз функціональних характеристик прецедентних френоменів особливо важливий під час дослідження газетного дискурсу, одним із завдань якого $є$ вплив на реципієнта. Реалізація цього завдання на вербальному рівні пов'язана 3 використанням одиниць, знайомих більшості представників лінгвокультурної спільноти, що регулярно актуалізуються в мовленні та зберігаються в колективній пам'яті його представників.

Аналіз досліджень $i$ публікацій... Висвітленню проблеми фрункціональних властивостей прецедентних френоменів присвячені роботи О. А. Земської, О. П. Семенець, Г. Г. Слишкіна, А. П. Чудінова (роль, яку прецедентні феномени виконують під час відтворення в мовленні); Д. Б. Гудкова, Ю. А. Гунько, Ю. М. Караулова, В. В. Красних (характер та мета використання прецедентних феноменів у мовленні) тощо.

Форлулювання иілей статті... Метою статті є аналіз функцій прецедентних феноменів у англомовному газетному дискурсі.

Виклад основного матеріалу... Досліджуючи прецедентні феномени, вчені виокремлюють різні фрункції: інформативну, оцінну, апелящійну, розважальну, декоративну персуазивну, номінативну, парольну, стилістичну (Боярських) [2, с. 60]; експресивну, оцінну, парольну (Д. Б. Гудков) [4]. 
У нашому дослідженні ми розглядаємо наступні фрункції прецедентних френоменів у газетному дискурсі: фрункцію характеризації, фрункцію експресивності, номінативну, парольну та маніпулятивну фрункції. Слід відмітити, що фуннкції прецедентних феноменів не обмежуються лише зазначеними нами, у газетному дискурсі можуть також актуалізовуватися інші фрункції, однак результати аналізу показали, що що ці фрункції $е$ найбільш домінантними у газетному дискурсі.

Д. Гудков стверджуе, що основною функцією прецедентних френоменів є фрункція характеризації [4, с.247]. На його думку прецедентні феномени у своєму конотативному вживанні виступають, як правило, як складові метафори або порівняння і слугують для уподібнення або зіставлення різних за своєю природою об'єктів. Саме статус прецедентного феномену як складника ядра когнітивної бази лінгвокультурної спільноти та високий ступінь його аксіологічності допомагає виявити фрункію характеризації прецедентного френомену у газетному дискурсі.

У нашому дослідженні ми виділяемо три основні типи актуалізації фрункції характеризації прецедентних френоменів у газетному дискурсі: через метафору, через порівняння, через вставне речення.

Варто зазначити, що «метафоричність» прецедентних феноменів полягає у використанні їх диференційних ознак для характеризації іншого предмета об’єктивної дійсності. У цьому випадку прецедентний феномен є добре відомим та легко впізнаваним мовцями і трактуеться адресатами як оптимально релевантний:

"There were smaller statements of support of the French people in the aftermath of the Charlie Hebdo shootings, too, most notably the "JeSuisCharlie" button Amal Clooney pinned to her satin Dior clutch." [Los Angeles Times, January, 2015]

У наведеному прикладі автор ототожнюе «JeSuisCharlie» 3 націею, що оплакуе невинних людей. Метафоричний вираз створено з метою засудження терористичних атак. За цією аналогією створено інший вираз "JesuisVolnovakha» з метою демонстрації підтримки та співчуття українському народу у війні на сході країни та у зв'язку з трагедією, яка сталася в 1914 році в місті Волноваха.

Наступний тип актуалізації ціеї функції прецедентного феномена використання у реченні порівняння, яке дає експліцитну характеристику предмета:

Italian politics is beginning to look like a season of Celebrity Survivor. And not only is Berlusconi the reigning champion..., he is also its executive producer. (Time, July 13, 2009) 
Автор статті порівнюе італійських політиків з учасниками телешоу «Celebrity Survivor», в основу якого покладено принщип усування своїх супротивників голосуванням.

Пряме посилання на прецедент, яке, здебільшого відбувається за допомогою вставних речень, $е$ ще одним типом актуалізації характеризації прецедентних френоменів. Автор висловлюе своє ставлення до предмета, який він описуе, за допомогою вставного речення, в якому наводить додаткову інформащію, що не має безпосереднього прямого зв’язку зі змістом статті.

Результати дослідження дають підстави стверджувати, що прецедентні феномени уможливлюють, 3 одного боку, відображення того, чого не можна відобразити за допомогою наявних мовних завобів, а 3 іншого боку, виразити це максимально точно та стисло. Для газетного дискурсу економія мовних засобів особливо актуальна, оскільки текст має свої фрізичні межі. У цьому випадку для привертання уваги часто використовуються візуальні засоби.

Н.Феркло вважає, що у випадку текстової економії автору не потрібно пояснювати те, що сприймаеться як само собою зрозуміле. Інтерпретатор повинен заповнити пропуски, зробити експліцитним те, що залишено імпліцитним, та сформувати когерентне значення тексту $[8$, c.123].

Наступною фрункцією прецедентних френоменів $е$ фрункція експресивності, яку розуміють як ознаку інтенсифікації значення слів за шкалою зменшення та збільшення різних денотативних та конотативних ознак, зокрема логічного змісту, оцінок й емотивності. Саме завдяки цій функції можна пояснити використання прецедентних феноменів навіть у випадку існування майже повних синонімів прямої номінації [4, с.257]:

She glances out the window at the hills where, she believes, David and Abraham once walked. (Time, July 27, 2009)

У цьому прикладі використовуються біблійні прецедентні імена «David» та «Abraham» замість більш загального терміна «біблійні патріархи». Вживання прецедентного френомена вимагае від реципіента складніших інтерпретативних процедур, ніж у випадку використання синонімів прямої номінації. Одніею 3 причин цього, на думку Д. Гудкова, e ефрект експресивності, який виникае при вживанні прецедентного френомена [4, с. 257].

При вживанні прецедентних френоменів у заголовках статей здебільшого спостерігається прояв двох фонкцій - експресивної та естетичної, причому не завжди можна чітко визначити яка із них $є$ домінантною: 


\section{Houston, We Have No Problems. (Newsweek, June 30, 2008)}

Функції характеризації та експресивності є основними фрункціями прецедентних феноменів у газетному дискурсі. Вони іноді можуть діяти паралельно, іноді спостерігається значна домінація або майже повна відсутність одніеї 3 них. Далі ми розглянемо додаткові функції прецедетних феноменів, які, тим не менше, у тексті відіграють важливу роль. На основі аналізу нам вдалось виявити такі додаткові функції прецедентних феноменів у газетному дискурсі: номінативну, парольну та маніпулятивну.

Номінативна функція прецедентних френоменів здійснюеться 3 метою економії мовних засобів за допомогою вказівки на особу, явище, подію, що $е$ значущими для реципіентів та які не вимагають додаткового опису чи пояснення. Однак важливим у цьому плані $є$ апелящія не до власне денотата, а до набору диференщійних ознак цього прецедентного феномену.

Наведемо приклади, коли прецедентний френомен вживається для позначення ширшої категорії об'єктів:

In that case, the coasts they protect would be exposed to the full fury of tomorrow's Katrinas. (Newsweek, May 17, 2010)

В аналізованому прикладі прецедентний феномен $\epsilon$ узагальнюючою назвою подібних явищ чи осіб. Слово Katrinas вжито для позначення стихійних лих, які загрожують руйнуваннями побережжю країни з боку Мексиканської Затоки.

Таким чином, однією з передумов для становлення френомена як прецедентного $е$ його здатність виконувати фрнкцію номінації, коли мовна одиниця починае вживатися не лише як власна назва для найменування одного об’екта, а як узагальнююча назва:

Парольна функція прецедентних феноменів є засобом ототожнення особи 3 певною лінгвокультурною спільнотою, оскільки завдяки реалізації ціеї фрункції здійснюеться усвідомлення людини як представника тієї чи іншої громади.

Розглядаючи парольну фрункцію, дослідники вважають, що вона спрямована на доведення чи емфатизацію належності відправника мовлення до тієї ж групи, що й адресат (Г.Слишкін) [6, с.99], полягає в тому, що прецедент виступае як певний код у системі розпізнавання «свій-чужий» і слугуе доказом належності адресанта до тіеї ж соціальної чи культурної групи, що й адресат (В.Алексеєва) [3, с.151-152].

Ю.Караулов вказуе на певні труднощі, які можуть виникнути при виокремленні парольної фонкції, оскільки прецедентні феномени «мають надособистісний характер, тобто добре відомі також широкому оточенню певної особистості, включаючи її попередників та сучасників» 
[5, с.216], а наявність парольної функції, фрактично, накладає певні обмеження на цю характеристику прецедентного френомену, адже пароль звужуе коло комунікантів, які можуть його успішно інтерпретувати.

Варто зазначити, що прецедентні феномени нащіонального рівня $є$ широко відомими саме певній національній лінгвокультурній спільноті, яка має спільну когнітивну базу, обмежену етнічними, національними, політичними рамками. А отже, представники інших лінгвокультурних спільнот без спеціальної підготовки не зможуть адекватно інтерпретувати чужі національні прецедентні феномени.

There's a reason Harry Truman's White House desk sign, THE BUCK STOPS HERE, has entered presidential mythology. (Time, July 20, 2009)

Так, прецедентний феномен, вжитий у наведеному прикладі, є малоінформативним для людей 3 іншою когнітивною базою і без додаткового пояснення він буде незрозумілим. Так, значення ціеї фрази, яка походить з гри в покер, розуміють як потребу прийняття важких рішень самому та неперекладання відповідальності на інших, а закріпилося воно після використання цього висловлення президентом Г.Труменом [7].

Отже, реалізація парольної фрункції прецедентного френомену $є$ умовою для прийняття тіеї чи іншої особи до свого кола. У більшості випадків прецедентні феномени, які використовуються у парольній фрункції, $є$ невідомими представникам інших лінгвокультурних спільнот.

Маніпулятивна фрункція прецедентних феноменів у газетному дискурсі - це функція прихованого впливу, неусвідомленого адресатом, на формування думок, переконань адресата та спонукання його до вчинення певних дій, вигідних маніпулятору. Найбільший маніпулятивний ефект при вживанні прецедентних френоменів досягається: 1) за рахунок їх включення у заголовок, початок чи кінещь статті; 2) через використання трансформованих прецедентних феноменів, коли в одній одиниці наявні два смисли - дослівний та глибинний; 3) через створення розширених метафоричних образів за допомогою прецедентних френоменів.

Для того щоб пустити процес уяви по потрібному руслу, вигідному маніпулятору, автори статей використовують прецедентні френомени у заголовку. Місце прецедентного френомену $е$ суттевим, наприклад, завдяки психологічному ефекту краще сприймаеться та запам'ятовуеться початок та кінець будь-якого повідомлення в дискурсі.

Ілюстрацією ціеї думки може слугувати назва статті "Tear Down This Wall» (Newsweek, April 20, 2009), де активізуеться прецедентне 
висловлювання Рональда Рейгана та промова, яку він виголосив у 1987 році у Берліні. Це висловлювання має конкретний денотат Берлінську стіну, проте прецедентне висловлювання асоціюється, перш за все, з боротьбою проти тоталітаризму та комунізму в східній Свропі у кінці 1980-х рр.

Висновки... Таким чином, фрункції прецедентних френоменів спрямовані на формування в читача певного ставлення до зображуваних подій, оскільки прецедентні френомени, вербально репрезентовані прецедентними іменами, прецедентними висловлюваннями чи прецедентними ситуаціями, дають позитивну чи негативну ощінку цим подіям. Знання особливостей когнітивних процесів дають змогу авторам керувати спряйняттям інформації реципіентами, створюючи відповідні установки.

Подальшого дослідження вимагають типи трансформацій прецедентних феноменів у масмедійному дискурсі.

\section{Список використаних джерел і літератури:}

1. Алексеева В.О. Прецедентные феномены современного российского политического дискурса. Воронеж: Воронежский государственный ун-т, 2004. C.149-153.

2. Боярских O. С. Прецедентные феномены со сферой-источником «Литература» в дискурсе российских печатных СМИ (2004-2007 гг.) : дис. ... канд. фрилол. наук : 10.02.01. Нижний Тагил, 2008. 230 с.

3. Великорода В.Б. Семантичні та фонкціонально-прагматичні характеристики евфемізмів в англійській мові: автореф. дис. на здобуття наук. ступеня канд. філол. наук: спец. 10.02.04. Львів, 2008. 20 с.

4. Гудков Д.Б. Прецедентные френомены в языковом сознании и межкультурной коммуникации: дис. ...доктора филол. наук: 10.02.19. Москва, 1999. $400 \mathrm{c}$. $264 \mathrm{c}$.

5. Караулов Ю.Н. Русский язык и языковая личность. Москва: Наука, 1987.

6. Слышкин Г.Г. От текста к символу: лингвокультурные конщепты прецедентных текстов в сознании и дискурсе. Москва: Academia, 2000. 128c.

7. Wikipedia. URL: www.wikipedia.org.

8. Fairclough N. Media discourse. Oxford University Press, 1995. 216 p.

\section{References:}

1. Alekseyeva V.O. Pretsedentnyye fenomeny sovremennogo rossiyskogo politicheskogo diskursa. Voronezh: Voronezhskiy gosudarstvennyy un-t, 2004. S.149-153.

2. Boyarskikh O. S. Pretsedentnyye fenomeny so sferoy-istochnikom «Literatura» v diskurse rossiyskikh pechatnykh SMI (2004-2007 gg.) : dis. ... kand. filol. nauk : 10.02.01 / Nizhniy Tagil, 2008. $230 \mathrm{~s}$. 
3. Velykoroda V.B. Semantychni ta funktsional'no-prahmatychni kharakterystyky evfemizmiv v anhliys'kiy movi: avtoref. dys. na zdobuttya nauk. stupenya kand. filol. nauk: spets. 10.02.04 / L'viv, 2008. $20 \mathrm{~s}$.

4. Gudkov D.B. Pretsedentnyye fenomeny $v$ yazykovom soznanii i mezhkul'turnoy kommunikatsii: dis. ...doktora filol. nauk: 10.02.19. / Moskva, 1999. $400 \mathrm{~s}$.

5. Karaulov YU.N. Russkiy yazyk i yazykovaya lichnost'. M.: Nauka, 1987. $264 \mathrm{~s}$.

6. Slyshkin G.G. Ot teksta $\mathrm{k}$ simvolu: lingvokul'turnyye kontsepty pretsedentnykh tekstov v soznanii i diskurse. M.: Academia, 2000. $128 \mathrm{~s}$.

7. Wikipedia. [Elektronnyy resurs]. - Rezhym dostupu: www.wikipedia.org

8. Fairclough N. Media discourse. Oxford University Press, 1995. 216 p.

\section{Summary \\ Liudmyla Vorotniak \\ Functioning of Precedent Phenomena in the English-Language Newspaper Discourse}

The article identifies and describes the main functions of precedent phenomena in the English-language newspaper discourse. It has been found that the characterization function is mostly manifested through metaphor, comparison or insertion structures; the function of expressiveness allows the addressee to achieve intensification and emotionality, expresses the text due to the expressiveness of the logical components; nominative function is carried out in order to save linguistic resources by means of an indication of a person, a phenomenon, an event that are significant for the recipients and do not require additional description or explanation; the password function is a means of identifying a person with a particular linguistic-cultural community and facilitate the integration of speakers within this community; manipulative function of precedent phenomena - is a function of hidden influence on the formation of opinions, beliefs and motivations of the recipient to perform certain actions favorable to manipulator.

The scientific sources devoted to the functioning of precedent phenomena are analyzed, which convincingly proves existence of different approaches to the problem and gives grounds to assert that precedent phenomena are multifunctional. Three main types of actualization of the function of characterization of precedent phenomena in the newspaper discourse are distinguished: through metaphor, through comparison, through the insertion sentence.

Key words: precedent phenomena, newspaper discourse, function of characterization, expressiveness function, password function, manipulative function.

Дата надходження статті: «17» жотвня 2018 р.

Дата прийняття до друку: «05» листопада 2018 р. 